\title{
Shaping of Flexibility in Urban Renewal Legal Sources in Turkey and Its Effect on Practices
}

\author{
Sezen Tarakçı ${ }^{1} \odot$, Şevkiye Şence Türk ${ }^{2} \odot$ \\ ${ }^{1}$ Lecturer, Faculty of Engineering and Architecture, Istanbul Arel University, Istanbul, Turkey. (Principal contact for editorial \\ correspondence), Email: sezentarakci@arel.edu.tr. \\ 2Prof. Dr., Faculty of Architecture, Istanbul Technical University, Istanbul, Turkey. Email: turkss@itu.edu.tr
}

\begin{abstract} Purpose

Discussions in planning systems of different countries under the influence of structural changes at the macro level are concentrated around flexibility and certainty. Since 2000, Turkey have triggered a shift in the planning system which is defined as regulatory in theory, towards a more flexible system in practice. This flexible system can be also seen in urban renewal practices. The aim of the article is to discuss the flexibility shaped by the legal sources with examples of urban renewal in Turkey.

Design/Methodology/Approach

As methodology, in the study, firstly, international and national literature on flexibility in planning systems was investigated. Afterwards, shaping flexibility in planning systems is focused on three categories; (1) spatial planning, (2) property rights, and (3) discretionary power. Legal sources related to urban renewal areas, and their practices are examined under three categories based on findings of some examples in literature.

\section{Findings}

The findings demonstrate that the increase in the degree of flexibility directly affects the spatial planning, property rights, and using of the discretionary power: Firstly, the scope and power of spatial plans are eliminated. Secondly, the property right, which is protected by the constitution, is ignored. Thirdly, since the limits of discretionary power are not clear, the outcomes of practices cannot be controlled either.

\section{Research Limitations/Implications}

The study based on findings of some examples in literature. In the study, no specific area study has been conducted.

\section{Social/Practical Implications}

As a result of these study, laws and regulations related to urban renewal can be rearranged in terms of property rights, discretion power and spatial planning. Thus, more livable cities can be created with the participation of people in urban renewal practices and the public benefit of planning.

\section{Originality/Value}

There are quite limited studies focus on shaping of flexibility, and its effects in urban renewal. The originality of this study is to examine the shaping of flexibility in legal sources related to urban renewal, and reflections into the practices.
\end{abstract}

Keywords: Flexibility, regulatory planning, legal sources, urban renewal practices, Turkey 


\section{INTRODUCTION}

Under the influence of structural changes at the macro level, discussions of planning systems in different countries are concentrated around the dilemma of "flexibility" and "certainty" (Ozkan \& Turk, 2016; Buitelaar \& Sorel, 2010; Rivolin, 2008). The current literature indicates that the place of flexibility in urban development is still trying to be defined by the professions (Munoz Gielen and Tasan-Kok, 2010; Tasan-Kok, 2008). Flexibility is directly affected by national and international economic, political, and social shifts. Generally speaking, flexibility has developed as both a cause and a consequence of the legal changes in the political, institutional, and planning processes (Ozkan \& Turk, 2016; Steele and Ruming, 2012; Buitelaar \& Sorel, 2010; Tasan-Kok, 2008; Booth, 2003). As changes occur in factors such as international relations, political structures, modes of production and social structure, they create differences within the dynamics of space and therefore the problems and expectations of its users. Consequently, this process brings about discrepancies in administrative structures and planning actions (Tekeli, 2012). In this respect, the tendency towards the concept of flexibility is particularly influenced by the four factors; (1) the balance between public and private sector actors in urban planning, (2) countries' planning approaches, (3) the financial strength of the public sector, and (4) the investment demands of the private sector (Ozkan, 2012).

In the planning literature, there is a reoccurring pairing between the concepts of regulatory planning and discretionary planning (Rivolin, 2008). The regulatory planning system has shown a move away from certainty towards flexibility. At the same time, the developments regarding sustainability and economic growth have led to rigid, inflexible discretionary planning systems that fail to realise the strategic policy vision (Steele \& Rumig, 2012). In regulatory planning systems where local spatial plans are legally binding, certainty is at the forefront. In this case, the development rights granted in the plans are valid from the moment they are approved. Planning decisions in this system are legally binding for everyone, and development rights are regulated in detail through plans (Munoz Gielen and Tasan Kok, 2010). In discretionary planning systems where local spatial plans are not legally binding, flexibility is at the forefront. In such systems, planning decisions provide strategies rather than define development rights; such rights are determined through the reconciliation and negotiation processes of each project (Rivolin, 2008: 169). In the cases of some European examples, that since plans take time to negotiate and prepare, the preoccupation was typically with projects, not plans. This provided the flexibility to respond to pressures for spatial development (Taşan-Kok, 2008).

While planning requires flexibility in the development of new projects, certainty is necessary to maintain development in cities and protect individual rights (Buitelaar and Sorel, 2010: 988). However, the proportion of certainty and flexibility in planning systems varies from country to country (Booth, 2003). For example, while the British and 
Dutch planning systems prioritize flexibility, the American and French systems place greater emphasis on legal certainty (Munoz, 2010; Buitelaar and Sorel, 2010: 983). A two-way trend was observed in the implementation of planning systems in the study that was commissioned by the European Commission. According to this study, countries with regulatory planning systems tend to have more flexibility, while countries with discretionary planning systems strive to provide more certainty (Booth, 1996). In other words, there is on the one hand an effort to create certainty concerning control over building in planning systems, while on the other there is a search for flexibility in decision-making processes (Booth, 1996: 10). As a matter of fact, many planning systems have hybridized the characteristics of regulatory and discretionary planning systems, which implies that the ideal system finds middle ground between certainty and flexibility (Kılınç and Turk, 2018 a,b; Steele and Ruming, 2012: 159).

Flexibility is also ensured by assigning discretionary powers to relevant authorities involved in decision making by means of legal regulations (Booth, 1996). In multi-actor decision-making processes, flexibility simplifies the decision-making mechanism and expedites the process (Tasan-Kok, 2008; Biggar and Siemiatycki, 2020). According to the findings of Biggar \& Siemiatycki, Toronto proves to be a good example to understand how both administrative and political discretion work interchangeably. The findings of Biggar and Siemiatycki's (2020) study demonstrates that while the landowners are looking for certainty about the construction right of their land, they also expect flexibility in giving them additional rights with the negotiation process. Some planning theorists consider that in circumstances where the use of discretion to evade or to vary policy carries risks (Catney and Henneberry, 2012). However, controlling development in an ad hoc and less predictable way creates legal uncertainty. In addition, when both politicians and urban planners are given much discretion, it becomes difficult to defend the public interest against demands by powerful actors (Buitelaar and Sorel, 2010). The negotiation process takes place outside of the realm of the legal processes in countries where flexibility in planning emerges as a characteristic of informal arrangements (Ozkan and Turk, 2016). For example, in Ireland, powerful interests use informal strategies to bypass the rules of formal planning system which can prevent the effect of their economic power on the decision-making (Fox-Rogers and Murphy, 2013:262).

In recent years, there has been a trend in planning systems with more flexibility and less rigid rules (Voltanen et al., 2017; Munoz Gielen and Tasan-Kok, 2010). In cities that have a planning system based on rigid rules, planning seems to be challenged in developing a creative approach that will balance the needs of the market with the public interest given the new developments. Instead, it appears that there is a correctiveregulatory trend to approve new developments within the rules and constraints of the existing system. Within this framework, local 
governments have made efforts to revise existing plans by evaluating individual requests rather than developing strategies for new developments in the city as a whole (Tasan-Kok, 2008; Munoz Gielen and Taşan-Kok, 2010).

The aim of this article is to analyse the flexibility and its consequences that have resulted from the legal regulations related to urban renewal by taking into consideration urban renewal practices in Turkey. International literature research shows us that flexibility is mostly shaped by less rigid rules in spatial planning, facilitating the intervention to property rights and increase in the existence of discretionary power. In Turkey, in renewal practices, the extent and content of such a flexibility that has emerged due to legal sources, have changed since 2004 significantly. Therefore, as methodology, the legal sources related to urban renewal (North Ankara Entrance Urban Transformation Project Law No. 5104, dated 2004; Law on Protection and Usage of Historical and Cultural Immovable Assets by Renewal Law No. 5366, dated 2005; Municipalities Law No. 5393 Item 73, dated 2005 and Amendment Law on Municipalities Law No. 5998, dated 2010; Transformation Law for Areas at Risk of Natural Disaster Law No. 6306, dated 2012) analysed in the sense of flexibilities that occurs in spatial planning, property rights, and by the using of discretionary power through sample areas.

Following the introduction, the features and characteristics of the regulatory planning system in Turkey are given. The third section examines how flexibility has shaped in urban renewal practices and planning system from past to present in Turkey. In the fourth section, flexibility and the consequences that have emerged in the legal sources about urban renewal practices since 2004 are comparatively analysed through various sample areas. Finally, in the last section, consequences such a flexibility, and suggestions in the legal resources related to urban renewal practices in Turkey are given.

\section{TURKISH PLANNING SYSTEM}

Planning systems are divided into regulatory planning systems and discretionary planning systems. In Turkey, urban planning is provided through the regulatory planning system (Tarakci and Turk, 2018; Ozkan and Turk, 2016; Keleş, 2012; Ünlü, 2006; Ersoy, 2000). The regulatory planning system is designed to lead the development of space in accordance with the decisions of the plan. It is transferred to the development plan of the new use decisions of the land in order to apply these decisions that have definite results (Rivolin, 2008). Rivolin (2008) defines the regulatory planning system as being based on "hierarchy," and "legally binding," characterised by "certainty" and "rigidity." One of the important characteristics of the Turkish planning system is the existence of a "hierarchical" order (Demir, 2009). Planning legislation consists of hierarchically interdependent planning scales (Demir, 2009; Ozkan, 2012). In addition, each subscale is expected to involve more information and detail compared to the scale above and include the 
necessary information and data of its unique scale, while at the same time preserving the main decisions (Ersoy, 2000). However, since the regulatory planning system has not been able to respond to the dynamics of a city within the last 25-30 years of planning history in Turkey, it is a fact that the upper scale planning approach has been disregarded by the local governments, and urban space development has become dependent on small-scale projects instead of plans, due to the influence of neoliberal policies. Today, especially in the development of big cities, it is almost entirely dependent on small-scale projects (BIB Urbanization Forum, 2009; Ozden, 2006). There is a view suggesting that for a plan to be binding for all real and juristic persons and to acquire legal document status, it needs to be adopted and approved by political decision makers (Keles, 2012). In Turkey, Reconstruction Law No. 3194 states that local spatial plans have to go into effect following the approval of the city council. In this sense, the framework presented by the planning approach and implementation is a regulatory system that highly depends on "certainty" and that sets the standards for all cities at the national level (Ünlü, 2006). In addition, plans that reach the suspension time limitation and are finalised are worthy of legal document status, with significant consequences that bind real and juristic persons (Keles, 2012). For this reason, each local spatial plan is a whole within itself and has its own legal qualifications (Ozkan, 2012).

It is understood from all this that Turkey's planning system is a regulatory planning system that depends on precision in terms of development legislation. However, in recent years, significant changes in this system, have triggered a shift in the planning system which is defined as regulatory in theory, towards a more flexible system in practice (Ozkan and Turk, 2016).

\section{SHAPING OF FLEXIBILITY IN URBAN RENEWAL PRACTICES IN TURKEY}

In Turkey under the influence of neoliberal policies, urban development was increasingly shaped by private sector dynamics, while the public sector took a more and more passive role (Tasan-Kok, 2008). However, such arrangements have adopted a non-flexible, prescriptive, and rigid planning approach, creating a conflict between growing investment pressure and planning (Tasan Kok, 2006). In managing changes in urban space, the planning system is based on a regulatory model. The literature often emphasizes that planning determined by "local plans" lack flexibility (Ozkan and Turk, 2016; Keleș, 2012; Taşan-Kok, 2006; Ozden, 2006; Ersoy, 2000). In this sense, the current planning system does not offer the flexibility and interpretation potential necessary for the management of such change (Ünlü, 2006). Those affected by plan have often attempted to make up for this shortcoming through local political relationships (Ozkan \& Turk, 2016). Moreover, the policies of 1990s period resulted in increased partial land development in urban areas, while at the same time central and local governments failed to make 
available both land and housing and establish mechanisms to inspect the suitability of new land and housing for detailed local plans (Unsal and Turk, 2014).

Until the early 2000s, there was no systematic urban renewal policy in Turkey. During this period, mostly small-scale developers practiced renewal at the single-building scale (Turk and Korthals Altes, 2010). Especially after the 1999 Marmara earthquake, the aging texture of the cities, the low quality of the building stock, and the existence of areas prone to geotechnical risks highlighted the importance of city-scale urban renewal practices (Guzey, 2016). Urban renewal was emphasised again as a risk mitigation tool for natural disasters (Kuyucu and Unsal, 2010). In beginning of the 2000s, the government adopted a housing-oriented policy. This policy has led to a construction boom with increasing investment pressure on inner city areas, which became important investment locations for the real estate sector (Ozkan and Turk, 2016). The pressure to increase the capital/land ratio due to rising land prices in rapidly growing cities, and the resulting demand for high density reconstruction of the non-functional or decentralisation of industrial zones into urban fringes, and an increased demand for the reconstruction of licensed or unlicensed residential buildings, along with the projects of local governments that are in competition to receive the capital in the era of globalisation, have raised the momentum of urban renewal practices (Kocabaş, 2005).

In recent years, Turkey's planning system has adopted a decision-making approach based on fragments of the cities rather than considering of a city as a whole, leading to an increasingly flexible according to market demands (Ozkan and Turk, 2016; Tasan-Kok, 2006). However, the flexibilities and open negotiation processes in the relations between local governments and the private sector, as is the case in countries with discretionary planning systems, did not emerge here (Turk, 2018).

Since this period, also urban renewal projects have progressed through project-led approaches, developing a dynamic structure. Such approaches were also supported by legislation specific to urban renewal (Tarakci and Turk, 2018). There are some consequences of this approach in urban renewal practices. The most important of these is gentrification (Islam and Sakizlioğlu, 2015; Gervan et.al., 2013; Ergun, 2006). Landowners are generally given new housing units in the project area in exchange for their own plots (Türkün, 2014). The houses, built with a project-based approach, are generally for middle- and high-income, so that, in most cases, landowners are not able to bear the cost of their new houses (Uzun, 2015; Gervan et.al, 2013). Because the newly created social and technical infrastructures cause the unit prices of housing to increase, and the actual property owners cannot live in the area (Gur \& Turk, 2014) the projects are conducted according to the demands of national and international capital, and as a result, these areas are gentrified ( Uzun, 2015; Türkün, 2014; Ergun, 2006). Groups such as de facto owners, occupiers, and tenants are generally unable to remain in areas post- 
renewal (Ozkan and Turk, 2016). So that gentrification is the most discussed issue for urban renewal practices in Istanbul such as Tarlabaşı, Sulukule and Ayazma (Türkün and Sarığlu, 2014). Studies show that gentrification is not a problem caused by local governments, but rather a consequence of greater powers restructuring and regulating urban production, and thus the displacement of the urban population (Uzun, 2015).

\section{'FLEXIBILITY' IN THE LEGISLATION ON URBAN RENEWAL}

In Turkey, legal sources have played important roles in urban renewal practices. These roles have been shaped by urban renewal practices that has gone into effect since the beginning of the 2000s. The common point of the legal arrangements is that they redefine planning as a structure that is flexible. In this respect, the flexibilities for urban renewal projects by these laws are explained in detail below.

Flexibility in urban renewal legal sources occurs in three different ways: 1-Flexibility that occurred by spatial planning, 2- Flexibility that occurred in property rights, 3- Flexibility that occurred by using of discretionary power. Flexibility that defined in legal sources has affected the urban renewal practices directly.

\section{Flexibility that Occurred in Spatial Planning}

In spite of the fact that Turkey planning system is plan-led, urban renewal implementations follow a project-based approach (Ozkan and Turk, 2016; Türkün, 2014; Tasan-Kok, 2008). The project-based approach adopted in urban renewal areas introduces a planning system determined by plan notes rather than detailed planning in which all development rights are determined, as in the regulatory planning system. For the most part, decisions required to be made in the plan are not provided in the plan itself, but in these notes; for instance, decisions regarding land use functions, development rights, parcel sizes, social and technical infrastructure areas, incentives related to development rights, etc. are provided in the plan notes (Ozkan and Turk, 2016). While plan notes were originally used to provide the details not indicated in the local spatial plans, their purpose has changed over time (Turk, 2018). Today, plan notes are used as the most effective tool that guides urban development (Tarakci and Turk, 2017). Although the plan, plan notes, and plan report are defined as a whole and consistent entity in our country's legislation, the implementation of urban renewal is carried out solely through plan notes. For example, in Fikirtepe urban renewal project, the implementation was made by depending on plan notes, and even, plan notes outstripped the plan (Tarakci and Turk, 2018). Moreover, in urban renewal practice, the usage function of the areas in the immediate vicinity of the project area, the balance of social and infrastructure areas, and density are not taken into account (Ocakçı et al., 2017). 
Urban renewal practices since 2004 are applied with special purposed laws that adopt the approaches of the discretionary planning system. Bektaş (2014) reveals that following Municipality Law No. 5393 in 2005 and Law No. 5998 in 2010, declarations of urban renewal areas gathered momentum, and that when the years of declaration in Ankara are examined, a $26 \%$ section was concentrated in the year 2005. At the same time, an 80,000-hectare residential area of Ankara includes about 45\% urban renewal areas, which further proves the extent of these areas. In addition to urban renewal practices being a planning option, declarations of urban renewal areas cover nearly half the city's residential area (Bektaş, 2014). This study shows that half of the urban area of an important city such as Ankara is constructed with the approach of discretionary planning system whereas the other half develops with the regulatory plan system (Tarakci and Turk, 2018). However, this distinction is not in two different areas, but the renewal areas are located in different parts of the city. For this reason, regulatory planning dominated by $50 \%$ of the city is ineffective with fragmented interventions.

Besides, in the special purposed laws related to urban renewal, there is no emphasis on spatial planning. For example, one of the most important aspects of the Law on Protection and Usage of Historical and Cultural Immovable Assets by Renewal No. 5366 is the common emphasis on project rather than on planning. This is to such a degree that the law in question mentions simply "renewal projects", without reference to local spatial plans, drawing up a plan and approval, or in short, with no information on anything with regards to planning (Ozden, 2013). The law in question makes no mention of a relation between the projects and the local spatial plans in use for the zone the projects refer to.

According to the latest legislation Law No. 6306 on the Transformation of Areas under Risk of Disaster came into the force in 2012, Ministry of the Environment and Urbanization is the most powerful authority in the implementation of an urban renewal project (Gur and Turk, 2014). Law No. 6306 gave identification, planning, and licencing power related to urban renewal areas to the Ministry. Especially considering the broad framework of the definitions for risky structures, risky areas and reserve spaces, the greatest flexibility is provided in the authorisation for planning; and thus, the Ministry is granted the flexibility to conduct any type and scale of plans as preferred. Article 57 of the Constitution imposes important duties on the state in terms of housing legislation. The state is obligated to take necessary precautions for the residence of its citizens in healthy housing. The measures taken under Law No. 6306 can be considered as measures to meet the need for healthy housing (Simsek, 2015). Based on this reason, Law No. 6306 grants administrations a very broad authority, and with this authority, flexibility is provided both in planning and implementation. This flexibility is especially used by the central government. In addition, construction companies seem to have a significant say in these processes. However, there would be much benefit 
to include the municipalities in the implementation. The municipalities' coordination of relations between the construction companies and their owners can facilitate implementation. The law prevents this function of the local governments by giving more authority to the Ministry (Üstün, 2014).

\section{Flexibility that Occurred in Property Rights}

The property right is protected by the 35th item of the Turkish Constitution, and these rights cannot be limited except for public interest. Urban renewal projects aim to restore derelict and obsolescent areas economically, socially, physically and environmentally over the long term to establish of healthy living spaces. From this point of view, urban renewal is a tool directly affects property rights (Tarakci and Turk, 2015). Therefore, the property rights has been key since the beginning of urban renewal projects and determine the way are managed by categorising the residents.

Since Turkey's urbanisation policies depend on day-to-day politics, there is a wide variety of property documents even in the same neighbourhood. Urban renewal practices are shaped depending on the legal status of the property (Şen and Turkmen, 2014), such as land allocation certificates, land titles and those without any certification. This confusion of property consequently creates profound distinctions between those who have land allocation certificates and land registration (title) documents, and those with no documentation. While those who with legal property can negotiate more with the municipalities during the agreement stage, those who without legal property are willing or obliged to accept offers in negotiations (Kuyucu and Ünsal, 2010). For example; The North Ankara Entrance Urban Renewal Project planned getting rid of the gecekondus in the area completely and building common spaces and high-rise buildings (Kütük İnce, 2006). Moreover, the city council holds the authority of the distributions at the end of the project, and there are no objective criteria for distributions, as it is based on agreements. That is, the city council has been authorised to determine the qualifications of houses and workplaces that will be given to real estate owners in accordance with the land amounts, the size that is required for property right ownership and the qualifications of the houses that will be given to owners of the gecekondus with land allocation certificates. However, the criteria for application of these acts are not explained by the law or its regulations. At this point, flexibility in the distribution of ownership at the end of the project has been enabled by allocating a great deal of flexibility to the municipalities.

Legal sources related to urban renewal give the discretion power to public authorities on important issues such as valuation and expropriation. This situation enables a great deal of flexibility in urban renewal practices. Within the scope of Law No.5366, for evacuating and demolishing the structures within renewal areas during the implementation process of the projects, the primary method is 
agreement. When no agreement can be reached, the method of expropriation for the estates in the possession of juristic persons is used. However, in order to expropriate, a public interest ruling is required. In the urban renewal process, urgent expropriation process is generally used. Comparing to standard expropriation process, urgent expropriation greatly speeds up the process. As a general feature, in expropriation processes related to urban renewal, compensation is determined according to the existing situation. Therefore, the compensation is quite low. For example, it is known that the price per square metre for the 360 Ofis Project built and sold after the Tarlabaşı Urban Renewal reached $\$ 7,500$. All five-storeys of the registered building right next to this project, on the other hand, was expropriated for 760,000 Turkish liras $(\$ 420,000)$. This means that this person whose building was expropriated will be unable to buy even a $100 \mathrm{~m} 2$ office from this project (Türkün and Sarıoğlu, 2014).

Also, flexibility in property rights presented by Law No. 6306. The law states that decisions can be made by at least two thirds of the landowners after liquidation in these risky areas, on the real estate where the risky structures are located, and at the reserve spaces. The land shares of the landowners not participating in the decision making are then sold to the rest of the landowners by auction based on their market value. In cases where sales are not made to the landowners, the land is purchased by the Ministry for its market value. If at least two thirds of the landowners cannot reach an agreement, land can be urgently expropriated by the Ministry of Environment and Urbanization, MHA (Mass Housing Authority) or the Administration. It is stated in the decision of the Constitutional Court, dated 27.02.2014 numbered E: 2012/87 K: $2014 / 41$, that the urgent expropriation to reorganize the real estate's residential status in the settlements at risk of disaster, is for public interest. Because the life safety of landowners is the most important factor here. The ratio of 2/3 stipulated by law has been criticised for not being based on objective data and life experiences (Özsunay, 2015). However, the explanation has been that this regulation was made out of the ordinary with a broader perspective on the law due to an intention to accelerate the procedures. However, the most fundamental issue here is the obligation to get the shares of the landowners who do not participate in the majority. This is considered a new situation where the consequences of non-participation are outlined as exclusion from that community (Kürşat, 2013).

\section{Flexibility that Occurred by the Using of Discretionary Power}

After 2004, the government began to institute legal regulations addressing area-scale urban renewal projects. Under these regulations, both the central and local governments are given discretionary power over urban renewal processes, which also provides a great deal of flexibility in urban renewal practices. Discretionary power is defined as "room for decisional manoeuvre possessed by the decision-maker" (Jowell 1973:178); "possibility of decision making by the administration, 
either freely or by choosing one of the options available under certain circumstances" (Yayla, 1990: 77). The most important actors of urban renewal implementation are the Central Administration (MHA, the Ministry of Environment and Urbanization, and local governments (Metropolitan Municipalities, Municipalities, and Special Provincial Administrations).

Since 2004, MHA gained general power in urban renewal areas with the amendments in the laws. Relocation of the low-income groups both living in gecekondu areas and collapsing city centres to remote areas by MHA has become one of the policies during this period. In 2010, Municipality Law No. 5998 went into effect for amendments to Article 73 of Law No. 5393. With this law, the authority of the municipalities was reduced, while the authority of the metropolitan municipalities were expanded. The law in question rules that the area to be declared an urban renewal area should be no smaller than 5 and no bigger than 500 hectares and that more than one place related to the project area may be declared one urban renewal area, provided that the total is no less than 5 hectares. On the other hand, there are no parameters for determining the size of the area. The law gives metropolitan municipalities discretion to determine the urban renewal area. For example, in the Maltepe district of Istanbul, a 93-hectare area has been declared the Başıüyük Neighbourhood Urban Renewal Area. The initial work on urban renewal in the area started with the "Protocol Regarding the Urban Renewal Project in Maltepe, Istanbul" signed by MHA, the Istanbul Metropolitan Municipality, and the Maltepe Municipality on February 24, 2006 (Şen and Türkmen, 2014). Six 14-storey blocks were built in this area by MHA in the first stage, and the process is ongoing. The most recent development is the approval of the land use plan for the area by the Istanbul Metropolitan City Council on March 18, 2017.

Another example is from Law No.5366, in Neslişah and Hatice Sultan Neighbourhoods (Sulukule), an area of about 9 hectares declared a renewal zone in 2005. By law, the project was carried out jointly, in accordance with a protocol signed by the Fatih Municipality, the Istanbul Metropolitan Municipality and MHA. Even though the project was cancelled due to the fact that it was contrary to the urban planning principles and public interest, the project was completed by the time the decisions was approved by the Court.

Until 2012, urban renewal areas are identified by local governments. However, in 2012, Law No. 6306 on the Transformation of Areas under Risk of Disaster, the latest legislation on this matter, delegated this power to the central government's Ministry of the Environment and Urbanization (Kuyucu, 2018). The justification of the Law No. 6306 is the risk of earthquake, is the most emphasised rationale for also urban renewal in Turkey. The JICA report regarding the risk of earthquakes (JICA, 2002) stated that there were more than 400 districts that required large-scale redevelopment or strengthening. The Istanbul Earthquake Master Plan (METU, ITU, BU, YTU and IMM, 2003) has further improved 
this analysis. However, Tarakci and Turk (2015) revealed in their study conducted throughout Istanbul that the urban renewal areas declared by the Ministry were not identified in light of the results of the JICA Report and the Istanbul Earthquake Master Plan, but instead based mainly on the housing market. For example, the Derbent district (Şen and Öktem Ünsal, 2014), which is located next to the Maslak-Büyükdere Hill and has the highest land prices in Istanbul, 92\% of which is composed of gecekondus, is worthy of attention for its unresolved urban renewal issues especially since the beginning of the 2000s. As a solution, the area was declared a "risky area" on 03.01.2013 by the decision of the Council of Ministers. This verdict for a risky area was annulled as a result of the lawsuit filed by the residents of the neighbourhood, in 2014, by the 13th division of the state council on the grounds that the area was declared risky based on "observational and general information, not a technical report." However, with another decision of the Council of Ministers on 03.01.2017, the area was once more announced as risky. Likewise, the characteristics of the reserve space, whether risky or not, were not clearly defined in the law, and the appointment of reserve spaces was left to the discretion of the administration. The Ministry of Environment and Urban Planning has identified 8 reserve areas of $34,704 \mathrm{~m}^{2}$ on the European side of Istanbul.

Another important discretion power given by Law No. 6306 is related to the restriction of use. The Ministry may request from the relevant authorities not to provide electricity, water and gas to the structures in risky areas or risky structures. This restriction of use was not found contrary to the Constitution. According to the decision of the Constitutional Court dated 27.02.2014, numbered E: 2012/87 K: $2014 / 41$, it is considered reasonable action to stop providing electricity, water and gas services for residents who refuse to evacuate the buildings that are at the stages of "evacuation and destruction," and thus force their evacuation. However, withholding the services of electricity, water and gas in accordance with this regulation is a threat to an individual's right to health. This may lead to the abnegation of a public benefit (health) which is superior in terms of ensuring the continuity of the project. On the other hand, the above-noted regulations are not compatible with the principle of uninterrupted provision of public services or the social state principle (Üstün, 2014).

This situation was enabled by the power of discretion given to authorities by the urban renewal legislations. From the point of view of the local governments, it is stated that the contribution of the public sector to the partnership is the planning of land use and supply of land, municipal services and infrastructure services, and most importantly, establishing and sustaining the communication between the public and the private sector (Ozden, 2006). With the introduction of the recent legal sources, the authority of the central government has increased, while the role of local governments has decreased regarding urban renewal. This situation 
Shaping of Flexibility in Urban Renewal Legal Sources in Turkey and Its Effect on Practices

demonstrates that discretionary powers are mostly held by the central government.

\section{GENERAL EVALUATION AND CONCLUSION}

Since 2000, Turkey have triggered a shift in the planning system which is defined as regulatory in theory, towards a more flexible system in practice. Existence of such a flexible system can be also seen in urban renewal practices. The aim of the article is to examine the flexibility shaped by the legal sources with examples of urban renewal in Turkey. In this article, the shaping of flexibility was examined under three headings in the study and some findings were reached.

First is related to flexibility that occur in spatial planning. A project-led approach has been adopted in urban renewal practices, moving away from the previously more plan-led system.

Spatial planning that decides about the future of the cities is made for the purpose of public interest. Spatial planning has some basic objectives. These are; first is to equitably distribute costs and benefits; the second is to provide social and technical infrastructure for public use in cities; the third is to ensure spatial and social integration; and the fourth is to provide spatial quality (Ozkan and Turk, 2016; Kim, 2011; Klosterman, 1996). However, it is seen that in urban renewal practices, many subject that need to be plans were not explained and plan's decisions left to the plan notes. Here, flexibility is provided by plan notes. For example, building heights, dimensions and shapes of structures, floor areas, architectural features, residential typologies, etc. determined by the plan notes. In actuality, these specifications are made very strictly in the traditional planning approach in Turkey. The freedom granted to the developer by the planning unit, with no guidance or restrictions imposed, causes the implemented projects to develop in an incompatible fashion to the texture of the surrounding residential areas (Ozkan and Turk, 2016). Moreover, throughout the process, starting with the planning until the end of the building license procedures, authorising only the Ministry causes a lack of inspection. On the other hand, varying from Turkey's planning system, especially in historic city areas, "project" instead of "plan" concept is brought to the foreground. The extent of flexibility has a direct effect on the provision of planning outcomes because uncertainty created by extreme flexibility can jeopardise the provision of the desired planning outcomes (Ozkan and Turk, 2015). At this point, the degree of flexibility is crucial for the balance between the benefit of the private sector and the public interest.

Second is related to flexibility that occur in property rights. Although all laws presume that "agreement forms the basis", negotiations, which are the basis for discretionary planning systems, have never been defined in the existing laws. The right to expropriation and even urgent expropriation creates pressure on property owners. Negotiations for agreements in cases where there are no equitable and equal rights do not have the attributes of an actual negotiation. The ratio of $2 / 3$ stipulated by 
law has been criticised for the obligation to get the shares of the landowners who do not participate in the majority. These obligations damage the property right of landowners. Making decisions with the majority provides flexibility regarding the right to property. Sometimes, land owners may have to leave where they live, or to sell their property very cheaply. Particularly in countries experiencing problems such as economic uncertainty such as Turkey, ownership of property is considered to be financially secure by society. So that although the recent laws and constitutional court decisions related to urban renewal are considered to be in the public interest due to the earthquake hazard, the fear of losing ownership of property can prevent urban renewal practices. So, the degree of flexibility has a critical significance in terms of protecting the ownership right of landowners living in urban renewal areas. In this condition, it is needed to urgently produce solutions that will both increase urban renewal practices and protect the property rights of individuals.

Third is related to flexibility that occur by using of discretionary power. From the identification of the area to undergo urban renewal to identification of property rights of owners a significant amount of discretionary power was given to the administrations. The discretionary power first was given to the municipalities, which are then transferred to metropolitan municipalities, and finally to the central government. The latest legal regulations in particular seem to transfer the powers held by local governments to the central government. According to the Constitutional Court's decision published on 23rd of July 2012 in the Official Gazette, both the aforementioned discretionary power and the project-led approach to the planning system were found reasonable. Thus, while in urban renewal practices, as the discretionary power of central or local governments increases, in the process, participation of the land owners decrease. Landowners have no idea about what happens to their property or living.

As a result of the increase in the degree of flexibility, it can be possible to a great uncertainty in society at the future. On the one hand, landowners experience uncertainty about how their building / neighborhood will be after urban renewal, while on the other hand developers are uncertain about the criteria of their projects. This uncertainty, on the other hand, causes the efforts of all actors to maximize their interests. Thus, urban renewal practices turn into an enrichment tool. This situation is in fact affect all society because no one can foresee any predictions about how the city will become in the future with uncontrolled planning. In this situation, it is clear that basic principles like protection of natural areas and cultural values, ensuring high social and technical infrastructure standards and quality and accessing all social groups will be damaged. At this point, it is necessary to control the increase of flexibility in order to protect the public interest and property right for the future of the cities. The article suggests that the balance in the degree of flexibility gains more importance in developing countries like Turkey. 
In countries where regulate in the degree of flexibility in planning systems, some regulations have been introduced on the negative effects of flexibility and how these effects can be controlled and managed by administrations in the urban area. Also, in countries where regulate in the degree of flexibility in planning systems, administrations attach importance to ensuring social equality in urban areas. In order to ensure social equality in urban space, it takes measures to ensure that different social groups live together in both urban renewal areas and the city's development areas. Therefore, arrangements are important for high standards and quality of social and technical infrastructure areas in urban areas and to ensure the access of all social groups. Again, in countries where regulate in the degree of flexibility in planning systems, principles for the protection of natural areas and cultural values are determined by administrations. If all this is achieved, flexibility can be controlled and managed.

In Turkey, to overcome the gap between theory and practice flexibility in three ways should be defined in legal sources related to urban renewal. For example, it should be known when plan notes will be used. Also, it should be known in which situations the discretion power will be used, and its limits. With defining of flexibility by means of legal regulations, taking place outside of the realm of the legal processes or using informal strategies to bypass the rules of formal planning system can be removed. Otherwise, flexibility as uncontrollable power might become the planning system unfunctional.

\section{ACKNOWLEDGEMENTS/NOTES}

This article is an excerpt from Sezen Tarakci's doctoral thesis titled "Proposal of a Method for Public Value Capture in Urban Renewal Areas: Fikirtepe Case", supervised by Prof. Dr. Sevkiye Sence Turk at Istanbul Technical University.

\section{CONFLICT OF INTEREST}

No conflict of interest was declared by the authors.

\section{FINANCIAL DISCLOSURE}

This thesis (Proposal of a Method for Public Value Capture in Urban Renewal Areas: Fikirtepe Case) has received a financial support that Graduate Thesis Support Program of Marmara Municipalities Union.

\section{ETHICS COMMITTEE APPROVAL}

Ethics committee approval was not required for this article.

\section{LEGAL PUBLIC/PRIVATE PERMISSIONS}

In this research, the necessary permissions were obtained from the relevant participants (individuals, institutions and organizations) during the survey, in-depth interview. 


\section{REFERENCES}

Bektaş, Y. (2014). Bir Kentleşme Stratejisi Olarak Yasanın Kentsel Mekanı Dönüştürmedeki Etkisi: Ankara Örneği (The Impact of Law on Transforming Urban Space as an Urbanization Strategy: The Case of Ankara), Planlama Dergisi (The Planning Journal), 3(24), 157-172 (in Turkish).

BIB Urbanization Forum (2009). Kentleşme Şurası (Cilt 1) (Urbanization Council, Volume 1). Ankara, Ministry of Public Works and Settlement (in Turkish).

Biggar, J. \& Siemiatycki, M. (2020) Tracing Discretion in Planning and Land-Use Outcomes: Perspectives from Toronto, Canada, Journal of Planning Education and Research 1-17, DOI: 10.1177/0739456X20904427

Booth, P. (1996) Controlling development Certainty and discretion in Europe, the USA and Hong Kong, Taylor and Francis, London.

Booth, P. (2003) Planning by Consent: The Origins and Nature of British Development Control, London, Routledge.

Buitelaar, E. \& Sorel, N. (2010) Between the rule of law and the quest for control: Legal certainty in the Dutch, Land Use Policy (27), 983-989.

Catney, P. \& Henneberry, J. (2012) (Not) Exercising Discretion: Environmental Planning and the Politics of Blame-Avoidance, Planning Theory \& Practice, Vol. 13, No. 4, 549-568

Ergun, N. (2006). Gentrification Kuramlarınin Istanbul'da Uygulanabilirliği (The Applicability of Gentrification Theories to Istanbul). D. Behar, \& T. İslam (Eds). Istanbul'da Soylulaștırma Eski Kentin Yeni Sahipleri (Gentrification in Istanbul: The New Owners of the Old City). Istanbul, Istanbul Bilgi Üniversitesi Yayınları (in Turkish).

Ersoy, M. (2000). İmar Planlarının Kademelenmesi ve Farklı Ölçeklerdeki Planlar Arasındaki İlişki (The Staging of Zoning Plans and Relationships between Plans of Different Scales). M. Ersoy \& C.. Keskinok (Eds), Mekan Planlama ve Yargı Denetimi (Space Planning and Judicial Control) Ankara, Yargı Yayınevi (in Turkish).

Gervan, A., Demir, H. \& Yılmaz, A. (2013) Kentsel dönüşüm projelerinde mülkiyet kazanımlarının ekonomik analizinin Ayazma Kentsel Dönüşüm Projesi örneğinde incelenmesi (Economic analysis for change of ownership in urban renewal projects based on Ayazma renewal project case), HKMO 14. Türkiye Harita Bilimsel ve Teknik Kurultayı, Ankara (in Turkish).

Gur, S. \& Turk, S. S. (2014). 6306 Sayılı Kanunla Yeniden Ortaya Çıkan Bina Ölçeğinde Kentsel Yenileme Pratiği: Bağcllar İlçesi Örneği (The Practice of Urban Renewal on a Building Level Reemerging with Law No. 6306: The Case of the Bağcllar District), 38. Dünya Şehircilik Günü Kolokyumu, Istanbul (in Turkish).

Fox-Rogers,L. \& Murphy,E. (2014) Informal strategies of power in the local planning system, Planning Theory, 13 (3), 244-268.

Guzey, Ö. (2016). The last round in restructuring the city: Urban regeneration becomes a state policy of disaster prevention in Turkey. Cities (50), 40-53. 
Shaping of Flexibility in Urban Renewal Legal Sources in Turkey and Its Effect on Practices

Islam, T., Sakızlığlu, B. (2015) The making of and resistance to state-led gentrification in Istanbul, Turkey. L. Lees; H.B. Shin, E. Lopez-Morales (Eds.) Global gentrifications: Uneven development and displacement (245264) .Bristol, Polity Press.

JICA (2002). Afet Önleme/Azaltma Temel Planı (Basic Disaster Prevention/Mitigation Plan). Istanbul, Istanbul Metropolitan Municipality (in Turkish).

Jowell, J. (1973). The legal control of administrative discretion. Public Law, 178-219.

Keleş, R. (2012). Kentleşme Politikaları (Urbanization Policies). Ankara, İmge Kitapevi (in Turkish).

Kılınc, N. \& Turk, S.S. (2018a) Planlama Sistemlerinde Hibritleşme ve Plan Değişikliğine Yaklaşımları (Approaches to Hybridization and Plan Change in Planning Systems), 18. Ulusal Bölge Bilimi ve Bölge Planlama Kongresi, Marmara Üniversitesi, İstanbul (in Turkish).

Kılınc, N. \& Turk, S.S. (2018b) Hybridisation in Planning Systems and its Effects on Legal Sources: Turkish Case, AESOP 2018, Gothenburg, Sweden.

Kim, J. H. (2011) Linking land use planning and regulation to economic development: A literature review, Journal of Planning Literature, 26 (1),35-47.

Klosterman, R. E. (1996), Arguments for and against planning. Campbell, S. and Fainstein, S. (Eds.), Readings in Planning Theory (150-168), Malden, MA, Blackwell.

Kocabaş, A. (2007). The Emergence of Istanbul's Fifth Urban Planning Period: A Transition to Planning for Sustainable Urban Regeneration, Journal of Urban Technology, 12(2), 27-48.

Kuyucu, T. \& Ünsal, Ö. (2010). 'Urban Transformation' as State-led Property Transfer: An Analysis of Two Cases of Urban Renewal in Istanbul, Urban Studies, 47(7), 1479-1499.

Kuyucu, T. (2018) Türkiye'de Kentsel Dönüşümün Dönüşümü: Hukuki ve Kurumsal Çatışmalar Üzerinden Bir Açılama Denemesi (The Transformation of Urban Transformation in Turkey: An Institutional Analysis), Idealkent, 24 (9), 364-386 DOI: 10.31198/idealkent.447526 (in Turkish).

Kürşat, Z. (2013). 6306 Sayılı Afet Riski Altındaki Alanların Dönüştürülmesi Hakkında Kanunun Özel Hukuk Alanındaki Etkileri (The Impact of Law No. 6306 Regarding Transformation of Spaces at Risk for Disaster on Private Law). M. Yasin \& C. Şahin (Eds.). Kentsel Dönüşüm Hukuku (Urban Transformation Law) (pp. 19-48). Istanbul, Istanbul Üniversitesi S.S. ONAR İdare Hukuku ve İlimleri Araştırma ve Uygulama Merkezi Yayınları (in Turkish).

Kütük İnce, E. (2006). Kentsel Dönüsümde Yeni Politika, Yasa ve Ĕ̈ilimlerin Degerlendirilmesi "Kuzey Ankara Giriși (Protokol Yolu) Kentsel Dönüsüm Projesi (A Review of New Policies, Laws and Tendencies in Urban Transformation "North Ankara Entrance (Protocol Way) Urban Transformation Project). Ankara, Gazi Üniversitesi Fen Bilimleri Enstitüsü (in Turkish). 
Munoz Gielen, D. \& Tasan-Kok, T. (2010). Flexibility in Planning and the Consequences for Public-value Capturing in the UK, Spain and the Netherlands, European Planning Studies, 18(7), 1097-1131.

Munoz Gielen, E. (2010) Capturing value increase in urban redevelopment. Leiden, Sidestone Press.

Ocakçı, M., Turk, S.S. \& Terzi F. (2017) Kentsel Dönüşüm Uygulamalarında Planlama Ilke ve Kriterleri (Planning Principles and Criteria in Urban Transformation Practices). Istanbul, Birsen Yayınevi (in Turkish).

METU-ITU-BU-YTU-IMM (2003). Istanbul için Deprem Master Planı (The Earthquake Master Plan for Istanbul). Istanbul, Istanbul Metropolitan Municipality (in Turkish).

Ozden, P. P. (2006). Türkiye'de Kentsel Dönüşümün Uygulanabilirliği Üzerine Düşünceler, I.Ü. Siyasal Bilgiler Fakültesi Dergisi (35), 215-233.

Ozden, P. (2013) Üst Ölçekli Planlamadan Projeci Yaklaşıma Planlamanın Değişen Yüzü (The Changing Face of Planning from Top Level Land Use Planning to Project Approach), K. Eyüpgiller, Z. Eres (Eds.) Mimari ve Kentsel Koruma Nur Akın'a Armağan (Architectural and Urban Conservation A Gift to Nur Akın) (pp. 417-436). Istanbul, Yem Yayınevi.

Ozkan, H. A. (2012). Planlama Sistemlerinde Esneklik Kavramı: Türkiye Üzerine Bir Analiz (The Concept of Flexibility in Planning Systems: An Analysis of Turkey). Istanbul, Istanbul Teknik Üniversitesi (in Turkish).

Ozkan, H. \& Turk, S.S. (2016). Emergence, formation and outcomes of flexibility in Turkish planning practice, IDPR, 38, 25-54.

Ozsunay, E. (2015). 6306 Sayılı Kanun ve Kentsel Dönüşüm Uygulamalarına İlişkin Düşünceler (Thoughts on Law No. 6306 and Urban Transformation Practices). Istanbul, Vedat Kitapçllı (in Turkish).

Rivolin, U. J. (2008). Conforming and Performing Planning Systems in Europe: An Unbearable Cohabitation, Planning, Practice \& Research, 23(2), 167-186.

Steele, W. \& Running, K. (2012). Flexibility Versus Certainty: Unsettling the Land-Use Planning Shibboleth in Australia, Planning, Pratice \& Research, 27(2), 155-176.

Şen, B. \& Türkmen, H. (2014). Başıbüyük- Bir Kentsel Dönüşüm Sınaması. A. Türkün (Eds.) Mülk, Mahal, Insan - Istanbul'da Kentsel Dönüşüm (Properties, Spaces, Humans - Urban Transformation in Istanbul) (s. 143188). Istanbul: Istanbul Bilgi Üniversitesi Yayınları (in Turkish).

Şen, B. \& Öktem Ünsal, B. (2014). Derbent- Memeleketin İşçi Mahallesi ya da Küresel Kentin "Hukuksuz" Gecekondu Alanı. A. Türkün (Eds.) Mülk, Mahal, Insan - Istanbul'da Kentsel Dönüşüm (Properties, Spaces, Humans Urban Transformation in Istanbul) (s. 189-225). İstanbul, İstanbul Bilgi Üniversitesi Yayınları (in Turkish).

Simsek, S. (2015). Türkiye'de Kentsel Dönüşüm Uygulamaları (Urban Transformation Practices in Turkey). Ankara, Seçkin Yayıncllık (in Turkish).

Tarakci, S. \& Turk, S.S. (2015). Istanbul'da Deprem Riskinin Azaltilmasi Gerekçesine Dayali Kentsel Yenileme Uygulamalari (Urban Renewal Practices in Istanbul Due to Mitigation of the Risk of Earthquake), 8th 
Shaping of Flexibility in Urban Renewal Legal Sources in Turkey and Its Effect on Practices

National Earthquake Engineering Conference, May 11-14, 2015, Istanbul (in Turkish).

Tarakci, S. \& Turk, S.S. (2017). Flexibility in Urban Renewal Practices: The Case of Turkey. AESOP Annul Congress, (pp. 2538-2552), Lizbon.

Tarakci, S. \& Turk, S.S. (2018) Impact of planning on land value in urban renewal practice: The case of Istanbul-Fikirtepe, FIG Congress, 2018, Istanbul.

Tasan-Kok, T. (2006). Küresel Bütünleşme Sürecinde Kurumsal ve Mekânsal Değișim: Budapește, Istanbul ve Varșova Örnekleri (Institutional and Spatial Change in the Process of Global Integration: The Cases of Budapest, Warsaw and Istanbul. A. Eraydın (Eds.). Değişen Mekan Mekânsal Süreçlere Illişkin Tartışma ve Araștırma Toplu Bakış: 1923-2003 (A Comprehensive Review of Changing Spaces, Discussion on Spatial Processes and Research: 1923-2003) (s. 307-339). Ankara, Dost Kitapevi Yayınları (in Turkish).

Tasan-Kok, T. (2008). Changing Interpretations of 'Flexibility' in the Planning Literature: From Opportunism to Creativity?, International Planning Studies, 13(3), 183-195.

Tekeli, İ. (2012). Türkiye Kent Planlamasının Yeniden Kurumsallaşmasını Düzenlerken Düşünülmesi Gerekenler Üzerine (On What to Consider as the Reinstitutionalization of Turkey's Urban Planning is Being Organized), Journal of the Chamber of City Planners (3-4), 53-65 (in Turkish).

Turk, S. S. \& Korthals Altes, W. K. (2010) Institutional capacities in the land development for housing on greenfiled sites in Istanbul, Habitat International, 34 (2), 183-195.

Turk, S.S. (2018) Comparison of the impacts of non-negotiable and negotiable developer obligations in Turkey, Habitat International, 75, 122-130.

Türkün A. (2014) Mülk, mahal, insan: İstanbul'da kentsel dönüşüm (pp. 79139). İstanbul, Bilgi Üniversitesi Yayınları (in Turkish).

Türkün, A. \& Sarıoglu, A. (2014) Tarlabașı: Tarihî Kent Merkezinde Yoksulluk ve Dışlanan Kesimler Üzerinden Yeni Bir Tarih Yazllıyor. A. Türkün (Eds.). Mülk, mahal, insan: İstanbul'da kentsel dönüşüm (pp. 267307). İstanbul, Bilgi Üniversitesi Yayınları (in Turkish).

Ünlü, T. (2006). Kentsel Mekânda Değişimin Yönetilmesi (Managing Change in the Urban Space), METU Journal of the Faculty of Architecture, 23(2), 63-92 (in Turkish).

Unsal, F., Turk, S.S. (2014) Legal and institutional context of urban planning and urban renewal in Turkey: Thinking about Istanbul. Gülden Erkut and M. Reza Shirazi (Eds.) The Case of Beyoğlu, Istanbul Dimensions of Urban Re-development. Berlin, Endformat GmbH.

Üstün, G. (2014). Kentsel Dönüşüm Hukuku (Urban Transformation Law). Istanbul, On İki Levha Yayıncılık (in Turkish).

Uzun, N. (2015). Istanbul'da Seçkinleştirmenin Üç Aşaması: Cihangir, Galata ve Tarlabaşı Üzerinden Bir Değerlendirme (Three Stages of Gentrification in Istanbul: A Review of Cihangir, Galata and Tarlabaşı). B. 
Duman \& İ. Coşkun (Eds.), Neden Nasıl ve Kim İçin Kentsel Dönüşüm (Urban Transformation - Why, How and For Whom) (s. 431-451). Istanbul, Litera Yayıncllık (in Turkish).

Voltanen, E, Falkenbach, H., Viitanen,K. (2017) Development-led planning practices in a plan-led planning system: empirical evidence from Finland, European Planning Studies, 25 (6), 1053-1075.

Yayla, Y. (2010) İdare Hukuku (Administrative law). Istanbul, Beta Yayınları (in Turkish)

\section{Resume}

Sevkiye Sence Turk is a Professor at the Department of Urban and Regional Planning in Faculty of Architecture, Istanbul Technical University (ITU). Her main interests are urban legal and administrative aspects in the development of the built environment, use of land readjustment (LR) in urban areas, land development processes, serviced land supply for housing and location theory.

Sezen Tarakci is an Instructor in Istanbul Arel University, Department of Architecture. Also she continues doctorate in Istanbul Technical University (ITU) Urban and Regional Planning Phd Programme. Her thesis is about land value capture in urban renewal areas. There are also studies on urban renewal and legal instruments. 